\title{
The Influence of Biomarker Mutations and Systemic Treatment on Cerebral Metastases from NSCLC Treated with Radiosurgery
}

\author{
Min Ho Lee, M.D., Doo-Sik Kong, M.D., Ph.D., Ho Jun Seol, M.D., Ph.D., Do-Hyun Nam, M.D., Ph.D., Jung-Il Lee, M.D., Ph.D. \\ Department of Neurosurgery, Samsung Medical Center, Sungkyunkwan University School of Medicine, Seoul, Korea
}

Objective : The purpose of this study was to analyze outcomes and identify prognostic factors in patients with cerebral metastases from non-small cell lung cancer (NSCLC) treated with gamma knife radiosurgery (GKS) particularly, focusing on associations of biomarkers and systemic treatments.

Methods : We retrospectively reviewed the medical records of 134 patients who underwent GKS for brain metastases due to NSCLC between January 2002 and December 2012. Representative biomarkers including epidermal growth factor receptor (EGFR) mutation, K-ras mutation, and anaplastic lymphoma kinase (ALK) mutation status were investigated.

Results : The median overall survival after GKS was 22.0 months (95\% confidence interval [Cl], 8.8-35.1 months). During follow-up, 63 patients underwent salvage treatment after GKS. The median salvage treatment-free survival was 7.9 months $(95 \% \mathrm{Cl}, 5.2-10.6$ months). Multivariate analysis revealed that lower recursive partition analysis (RPA) class, small number of brain lesions, EGFR mutation (+), and ALK mutation (+) were independent positive prognostic factors associated with longer overall survival. Patients who received target agents 30 days after GKS experienced significant improvements in overall survival and salvage treatmentfree survival than patients who never received target agents and patients who received target agents before GKS or within 30 days (median overall survival: 5.0 months vs. 18.2 months, and 48.0 months with $p$-value=0.026; median salvage treatment-free survival: 4.3 months vs. 6.1 months and 16.6 months with $p$-value $=0.006$, respectively). To assess the influence of target agents on the pattern of progression, cases that showed local recurrence and new lesion formation were analyzed according to target agents, but no significant effects were identified.

Conclusion : The prognosis of patients with brain metastases of NSCLC after GKS significantly differed according to specific biomarkers (EGFR and ALK mutations). Our results show that target agents combined with GKS was related to significantly longer overall survival, and salvage treatment-free survival. However, target agents were not specifically associated with improved local control of the lesion treated by GKS either development of new lesions. Therefore, it seems that currently popular target agents do not affect brain lesions themselves, and can prolong survival by controlling systemic disease status.

Key Words : Non-small cell lung cancer · EGFR · K-ras · ALK · Gamma knife radiosurgery.

- Received: April 11, 2016 •Revised: August 22, 2016 •Accepted: August 30, 2016

- Address for reprints : Jung-II Lee, M.D., Ph.D.

Department of Neurosurgery, Samsung Medical Center, Sungkyunkwan University School of Medicine, 81 Irwon-ro, Gangnam-gu, Seoul 06351, Korea Tel : +82-2-3410-3494, Fax : +82-2-3410-0048, E-mail : jilee@skku.edu

This is an Open Access article distributed under the terms of the Creative Commons Attribution Non-Commercial License (http://creativecommons.org/licenses/by-nc/4.0) which permits unrestricted non-commercial use, distribution, and reproduction in any medium, provided the original work is properly cited. 


\section{INTRODUCTION}

Brain metastases occur in $30 \%$ to $50 \%$ of patients with non-small cell lung cancer (NSCLC) and are associated with poor prognosis and reduced quality of life ${ }^{15,19,31,36,37)}$. The median survival of patients who receive supportive care is approximately 1 to 2 months ${ }^{15}$. Primary approaches to the treatment of brain metastases include whole brain radiation therapy (WBRT), surgery, and stereotactic radiosurgery (SRS) techniques such as gamma knife radiosurgery (GKS), with median survival times that range from 6.5 months to 10 months ${ }^{2,3,28,32,34)}$. Long-term survival has been achieved in some patients who have undergone either surgery or radiotherapy and aggressive thoracic surgery, with studies reporting 5 -year survival rates of $10 \%$ to $20 \%{ }^{7-9,26)}$.

Recently, biomarker target agents have been developed and have led to improvements in progression-free survival and overall survival of advanced NSCLC patients ${ }^{18,20)}$. Target agents are now regularly considered among the initial treatment options for cerebral metastases from NSCLC.

The purpose of this study is to analyze outcomes and identify prognostic factors, concentrating on the roles of biomarkers and systemic treatment, in patients treated with GKS for cerebral metastases from NSCLC. We conducted a retrospective study of patients treated at a single institute between 2002 and 2012 and focused on how the evolving systemic management of NSCLC affected outcomes of patients treated with GKS for brain metastases.

\section{MATERIALS AND METHODS}

We retrospectively reviewed the medical records of $817 \mathrm{pa}-$ tients who underwent GKS for brain metastases from NSCLC between January 2002 and December 2012 at our institute. Among these patients, 134 patients with pretreatment data available for epidermal growth factor receptor (EGFR) mutation, K-ras mutation, and anaplastic lymphoma kinase (ALK) mutation were included in analysis. The median age of the patients in the sample was 59 years (range, 30-81 years); 76 were men and 58 were women. Adenocarcinoma was identified in 118 (88.1\%) patients; squamous cell carcinoma, in 3 (2.2\%) patients; and pathology was not determined in 13 (9.7\%) patients. The mode of onset of brain metastasis was synchronous in 82 patients (61.2\%) and metachronous in 52 patients (38.8\%). At the time of diagnosis, the median number of brain lesions was 2 (range, 1-10), and 45 (33.6\%) patients had a single brain lesion. The study protocol was reviewed and approved by the Institutional Review Board of Samsung Medical Center (SMC 2013-12-078-001), and adhered to the recommendations of the Declaration of Helsinki for biomedical research involving human subjects (1975).

GKS was performed with a Leksell Gamma Knife model B, C, or Perfexion (Elekta AB, Stockholm, Sweden). The median marginal dose of $20 \mathrm{~Gy}$ (range: 8-30) at 50\% isodose of maximum dose was prescribed. Magnetic resonance images (MRI) were taken every 3 months after initial GKS unless the patient developed new neurological symptoms. If MRI indicated good control of brain lesion after one year, then subsequent MRIs were taken every 6 months. If progression was noted, salvage treatment was performed or MRI was followed for one month to decide if salvage treatment was warranted. Progression on MRI was classified according to 3 different patterns including local recurrence, development of new lesions, and leptomeningeal seeding (LMS). Salvage treatment modality was chosen individually for each patient. Repeat GKS was performed in patients with small numbers of lesions, including both local recurrences and new lesions. Finally, 81 patients received GKS once, 26 received GKS twice, and 27 received GKS more than three times. Whole brain radiation therapy was chosen when the number of lesions exceeded 10 or leptomeningeal seeding was suspected. Target agents were generally used at the discretion of the treating medical oncologist based on standard treatment algorithms specific to the genomic type of each patient.

\section{Molecular pathology analysis}

The mutational analyses of EGFR (exon 18-21) and K-ras (exon 2,3) were performed by using directional sequencing of PCR fragments amplified from genomic DNA. The results 
were regarded as positive if a mutation was detected in both the forward and reverse DNA strands. ALK rearrangement was assessed by immunohistochemistry. Samples showing strong diffuse ALK positivity in the cytoplasm were regarded as positive. More details of the technique have been described elsewhere ${ }^{12,20,21)}$. Molecular analyses was performed on the primary lesions and presumed to be representative of metastatic lesions.

\section{Statistical analysis}

Overall survival was calculated from the date of initial GKS of brain metastases to the final follow-up period. Salvage treatment-free survival was calculated from the date of initial GKS of brain metastases to subsequent treatment for brain lesions. Time to event data were summarized using Kaplan-Meier plots, and the log-rank test was used to determine significant differences between groups. Univariable and multivariable analyses were performed using the Cox regression model. $p$-values $<0.05$ were considered statistically significant. The estimated hazard ratios (HRs) and 95\% confidence intervals (CIs) are reported. Statistical analyses were performed using commercial software (IBM SPSS Statistics, version 20.0, IBM Corp., Armonk, NY, USA).

\section{RESULTS}

Survival analysis was performed with the sample of 134 patients who had data available for all three mutation types (EGFR, K-ras, and ALK). At the last follow-up, 67 patients had died, 49 were alive, and 18 had been lost to follow-up. The median duration of overall survival was 22.0 months (95\% CI, 8.8-35.1 months). The median duration of salvage treatment-free survival was 7.9 months (95\% CI, 5.2-10.6 months). During follow-up, 63 patients received salvage treatment: 50 patients received repeat GKS, 5 patients received WBRT, 4 patients received ventriculo-peritoneal shunt, 3 patients underwent Ommaya reservoir insertion for intra-thecal chemotherapy, and the final patient underwent re-operation.

\section{Survival analysis}

Multivariable analysis was performed to identify factors that predicted improved outcomes, overall survival. On multivariable analysis, 11 potential prognostic factors-age, sex, RPA classification, pathologic diagnosis, mode of onset, tumor number, tumor volume, prescribed radiation dose, and mutation status of EGFR, K-ras, and ALK-were considered. Age, sex, pathologic diagnosis, mode of onset, tumor volume, prescribed dose, and a mutation status of K-ras were excluded as independent prognostic factors, while the remaining four factors-lower RPA class, tumor number, EGFR mutation $(+)$ and ALK mutation (+)-were identified as independent positive prognostic factors related to the prolonged overall survival (Table 1).

\section{Effect of target agents on GKS}

Among 134 patients the numbers of patients who received at least first, second, or third lines of systemic chemotherapy were $130(97.0 \%), 102(76.1 \%)$, and $75(56.0 \%)$, respectively. During the follow-up period pemetrexed was prescribed in 93 patients, gefitinib in 54 patients, erlotinib in 35 patients, and crizotinib in 16 patients. Table 2 shows chemotherapy regimens in relation to EGFR, K-ras, and ALK mutation status.

Categorized by target agents, 17 patients never received target agents (group A), 86 patients received target agents before the GKS or within 30 days (group B), and the other 31 patients received target agents 30 days after receiving the GKS (group C).

We compared overall survival and salvage treatment-free survival. Patients from group C, who received target agents after receiving GKS had a significant improvement in overall survival, and salvage treatment-free survival (Table 3). Median overall survival was 5.0 months in group A, 18.2 months in group $\mathrm{B}$, and 48.0 months in group $\mathrm{C}$ with a $p$-val$\mathrm{ue}=0.026$. In particular, between group $\mathrm{A}$ and $\mathrm{C}$, group $\mathrm{B}$ and $\mathrm{C}$ showed significant differences $(p=0.006, p=0.024$, respectively) (Fig. 1A). Median salvage treatment-free survival was 4.3 months in group A, 6.1 months in group B, and 16.6 months in group $\mathrm{C}$ with $p$-value $=0.006$. In particular, be- 
Table 1. Survival analysis for overall survival

\begin{tabular}{|c|c|c|c|c|}
\hline \multirow{2}{*}{ Variables } & \multicolumn{2}{|c|}{ Univariable } & \multicolumn{2}{|c|}{ Multivariable } \\
\hline & HR $(95 \%$ Cl) & $p$-value & HR $(95 \%$ Cl) & $p$-value \\
\hline $\begin{array}{l}\text { Age (yr) } \\
\qquad \begin{array}{l}<60 \text { vs. } \geq 60 \\
<65 \text { vs. } \geq 65 \\
<70 \text { vs. } \geq 70\end{array}\end{array}$ & $\begin{array}{l}1.17(0.71-1.92) \\
1.11(0.63-1.95) \\
1.12(0.64-2.36)\end{array}$ & $\begin{array}{l}0.546 \\
0.712 \\
0.530\end{array}$ & $0.91(0.40-2.05)$ & 0.813 \\
\hline $\begin{array}{l}\text { Sex } \\
\text { Male vs. female }\end{array}$ & $0.51(0.30-0.84)$ & 0.009 & $0.57(0.32-1.01)$ & 0.055 \\
\hline $\begin{array}{l}\text { RPA class } \\
\qquad \begin{array}{l}\text { | vs. I| } \\
\text { | vs. I|| }\end{array}\end{array}$ & $\begin{array}{l}0.90(0.43-1.88) \\
3.06(1.37-6.85)\end{array}$ & $\begin{array}{r}<0.001 \\
0.784 \\
0.007\end{array}$ & $\begin{array}{l}0.74(0.32-1.71) \\
2.78(1.09-7.07)\end{array}$ & $\begin{array}{r}<0.001 \\
0.480 \\
0.032\end{array}$ \\
\hline $\begin{array}{l}\text { Pathologic difference } \\
\text { Adenocarcinoma } \\
\text { vs. squamous cell carcinoma }\end{array}$ & $7.61(1.74-33.23)$ & $\begin{array}{l}0.024 \\
0.007\end{array}$ & $1.96(0.39-9.78)$ & $\begin{array}{l}0.622 \\
0.412\end{array}$ \\
\hline $\begin{array}{l}\text { Mode of onset } \\
\text { Synchronous vs. metachronous }\end{array}$ & $1.64(1.01-2.66)$ & 0.046 & $1.58(0.89-2.78)$ & 0.116 \\
\hline $\begin{array}{l}\text { No. of brain lesions } \\
\text { Single vs. multiple } \\
<3 \text { vs. }>3 \\
<5 \text { vs. }>5\end{array}$ & $\begin{array}{l}2.12(1.19-3.78) \\
1.70(1.02-2.82) \\
2.20(1.24-3.88)\end{array}$ & $\begin{array}{l}0.011 \\
0.041 \\
0.007\end{array}$ & $2.29(1.21-4.34)$ & 0.011 \\
\hline $\begin{array}{l}\text { Total tumor volume }\left(\mathrm{mm}^{3}\right) \\
\quad<3000 \text { vs. } \geq 3000 \\
<5000 \text { vs. } \geq 5000 \\
<7000 \text { vs. } \geq 7000\end{array}$ & $\begin{array}{l}1.43(0.89-2.33) \\
1.52(0.93-2.49) \\
1.29(0.76-2.18)\end{array}$ & $\begin{array}{l}0.142 \\
0.095 \\
0.343\end{array}$ & $1.05(0.56-1.98)$ & 0.885 \\
\hline $\begin{array}{l}\text { Prescribed radiation dose } \\
\leq 15 \text { Gy vs. }>15 \mathrm{~Gy} \\
\leq 17 \mathrm{~Gy} \text { vs. }>17 \mathrm{~Gy} \\
\leq 18 \mathrm{~Gy} \text { vs. }>18 \mathrm{~Gy}\end{array}$ & $\begin{array}{l}0.99(0.36-2.75) \\
0.65(0.34-1.25) \\
0.61(0.35-1.08)\end{array}$ & $\begin{array}{l}0.994 \\
0.198 \\
0.089\end{array}$ & $0.92(0.43-1.95)$ & 0.819 \\
\hline EGFR mutation & $0.44(0.25-0.76)$ & 0.003 & $0.27(0.13-0.53)$ & $<0.001$ \\
\hline K-ras mutation & $1.28(0.55-2.96)$ & 0.566 & $0.77(0.27-2.19)$ & 0.626 \\
\hline ALK mutation & $0.66(0.33-1.34)$ & 0.250 & $0.38(0.17-0.87)$ & 0.022 \\
\hline
\end{tabular}

HR : hazard ratio, Cl : confidence interval, EGFR : epidermal growth factor receptor, ALK : anaplastic lymphoma kinase

tween group A and C, group B and C showed significant differences $(p=0.001, p=0.012$, respectively) (Fig. 1B).

\section{The patterns of progression and the manner of using target agents}

Progression after initial GKS was evaluated. Progression in any pattern during the follow up was observed in 79 (58.94\%) patients. Local recurrence of tumors was seen in 19 patients (14.2\%). New lesions were found in 43 patients (32.1\%), while 8 patients $(6.0 \%)$ had both local recurrence and new lesions, and 9 patients (6.7\%) had LMS. Nine patients (6.7\%) showed improved images before death or loss to follow-up, and the other 46 patients $(34.3 \%)$ had no images before death or loss to follow-up. Among the patients who showed progression, 50 patients received GKS for salvage treatment (Table 4). To determine the influence of target agents on the pattern of progression, cases that showed local recurrence and new lesions were analyzed using target agents. Among target agents never used, upfront used, and after used, there were no significant differences (Fig. 2).

Causes of death were analyzed from 67 expired cases. 26 patients $(38.8 \%)$ were expired due to pulmonary complication, i.e. pneumonia secondary to disease progression. Two 
Table 2. Patterns of palliative chemotherapy in relation to EGFR, K-ras, and ALK mutation status $(n=134)$

\begin{tabular}{|c|c|c|c|c|c|c|}
\hline $\begin{array}{l}\text { First line therapy, } \\
n=130\end{array}$ & $\begin{array}{l}\text { EGFR mutation (+), } \\
\qquad \mathrm{n}=49\end{array}$ & $\begin{array}{l}\text { EGFR mutation (-), } \\
\qquad \mathrm{n}=81\end{array}$ & $\begin{array}{l}\text { K-ras mutation (+), } \\
\mathrm{n}=10\end{array}$ & $\begin{array}{l}\text { K-ras mutation (-), } \\
n=120\end{array}$ & $\begin{array}{c}\text { ALK mutation (+), } \\
n=22\end{array}$ & $\begin{array}{c}\text { ALK mutation (-), } \\
n=98\end{array}$ \\
\hline Taxane-based & 8 & 8 & 2 & 14 & 4 & 10 \\
\hline Gemcitabine-based & 14 & 32 & 4 & 42 & 5 & 37 \\
\hline Pemetrexed & 11 & 32 & 4 & 40 & 7 & 33 \\
\hline Gefitinib & 12 & 0 & 0 & 12 & 0 & 12 \\
\hline Erlotinib & 2 & 1 & 0 & 3 & 1 & 2 \\
\hline Other regimens & 7 & 2 & 0 & 9 & 5 & 4 \\
\hline $\begin{array}{l}\text { Second line therapy, } \\
n=102\end{array}$ & $\begin{array}{l}\text { EGFR mutation (+), } \\
\qquad \mathrm{n}=40\end{array}$ & $\begin{array}{l}\text { EGFR mutation (-), } \\
\qquad \mathrm{n}=62\end{array}$ & $\begin{array}{c}\text { K-ras mutation (+), } \\
n=6\end{array}$ & $\begin{array}{c}\text { K-ras mutation }(-) \text {, } \\
n=96\end{array}$ & $\begin{array}{c}\text { ALK mutation (+), } \\
n=18\end{array}$ & $\begin{array}{c}\text { ALK mutation (-), } \\
\mathrm{n}=84\end{array}$ \\
\hline Taxane-based & 2 & 8 & 1 & 9 & 1 & 9 \\
\hline Gemcitabine-based & 1 & 8 & 2 & 7 & 4 & 5 \\
\hline Pemetrexed & 9 & 23 & 2 & 30 & 6 & 26 \\
\hline Gefitinib & 14 & 13 & 1 & 26 & 4 & 23 \\
\hline Erlotinib & 13 & 5 & 0 & 18 & 1 & 17 \\
\hline Other regimens & 1 & 5 & 0 & 6 & 2 & 4 \\
\hline $\begin{array}{l}\text { Third line therapy, } \\
n=75\end{array}$ & $\begin{array}{l}\text { EGFR mutation (+), } \\
\qquad \mathrm{n}=27\end{array}$ & $\begin{array}{l}\text { EGFR mutation (-), } \\
\qquad \mathrm{n}=48\end{array}$ & $\begin{array}{c}\text { K-ras mutation (+), } \\
n=3\end{array}$ & $\begin{array}{c}\text { K-ras mutation (-), } \\
n=72\end{array}$ & $\begin{array}{c}\text { ALK mutation (+), } \\
n=16\end{array}$ & $\begin{array}{c}\text { ALK mutation (-), } \\
\mathrm{n}=59\end{array}$ \\
\hline Taxane-based & 4 & 5 & 0 & 9 & 1 & 8 \\
\hline Gemcitabine-based & 7 & 9 & 0 & 16 & 2 & 14 \\
\hline Pemetrexed & 12 & 6 & 1 & 17 & 2 & 16 \\
\hline Gefitinib & 2 & 9 & 1 & 10 & 2 & 9 \\
\hline Erlotinib & 1 & 7 & 1 & 7 & 1 & 7 \\
\hline Other regimens & 1 & 5 & 0 & 13 & 8 & 5 \\
\hline
\end{tabular}

EGFR : epidermal growth factor receptor, ALK : anaplastic lymphoma kinase

Table 3. Target agent use and survival analysis

\begin{tabular}{|c|c|c|c|c|}
\hline \multirow{2}{*}{ Use of target agents } & \multicolumn{2}{|c|}{ Overall survival } & \multicolumn{2}{|c|}{ Salvage treatment-free survival } \\
\hline & Median, $95 \% \mathrm{Cl}$ (mon) & $p$-value & Median, $95 \% \mathrm{Cl}$ (mon) & $p$-value \\
\hline Group A, n=17 & $5.0(0-16.6)$ & 0.026 & $4.3(3.2-5.3)$ & 0.006 \\
\hline Group B, $n=86$ & $18.2(9.5-27.0)$ & & $6.1(3.2-8.9)$ & \\
\hline Group C, $n=31$ & $48.0(25.6-70.3)$ & & $16.6(4.8-28.4)$ & \\
\hline
\end{tabular}

Group A : patients who never received target agents; Group B : patients who received target agents before GKS or within 30 days; Group C : patients received target agents 30 days after receiving GKS. Cl : confidence interval, GKS : gamma knife radiosurgery

patients $(3.0 \%)$ had liver failure induced by hepatic metastasis. Two patients $(3.0 \%)$ had heart failure (malignancy related constrictive pericarditis, and acute coronary syndrome). One patient (1.5\%) expired by kidney failure. Other 2 patients (3.0\%) expired by intracranial reason, which were status epilepticus induced by increased intracranial pressure. The other 34 patients $(50.7 \%)$ were expired with unknown cause.

\section{DISCUSSION}

Several previous studies, including one of our own, have discussed the impact of tumor number or volume on prognosis $^{4,5,11,22,40)}$. However, genetic profiles have recently been determined to be significant prognostic factors. In the present study, we found that patients with EGFR or ALK muta- 

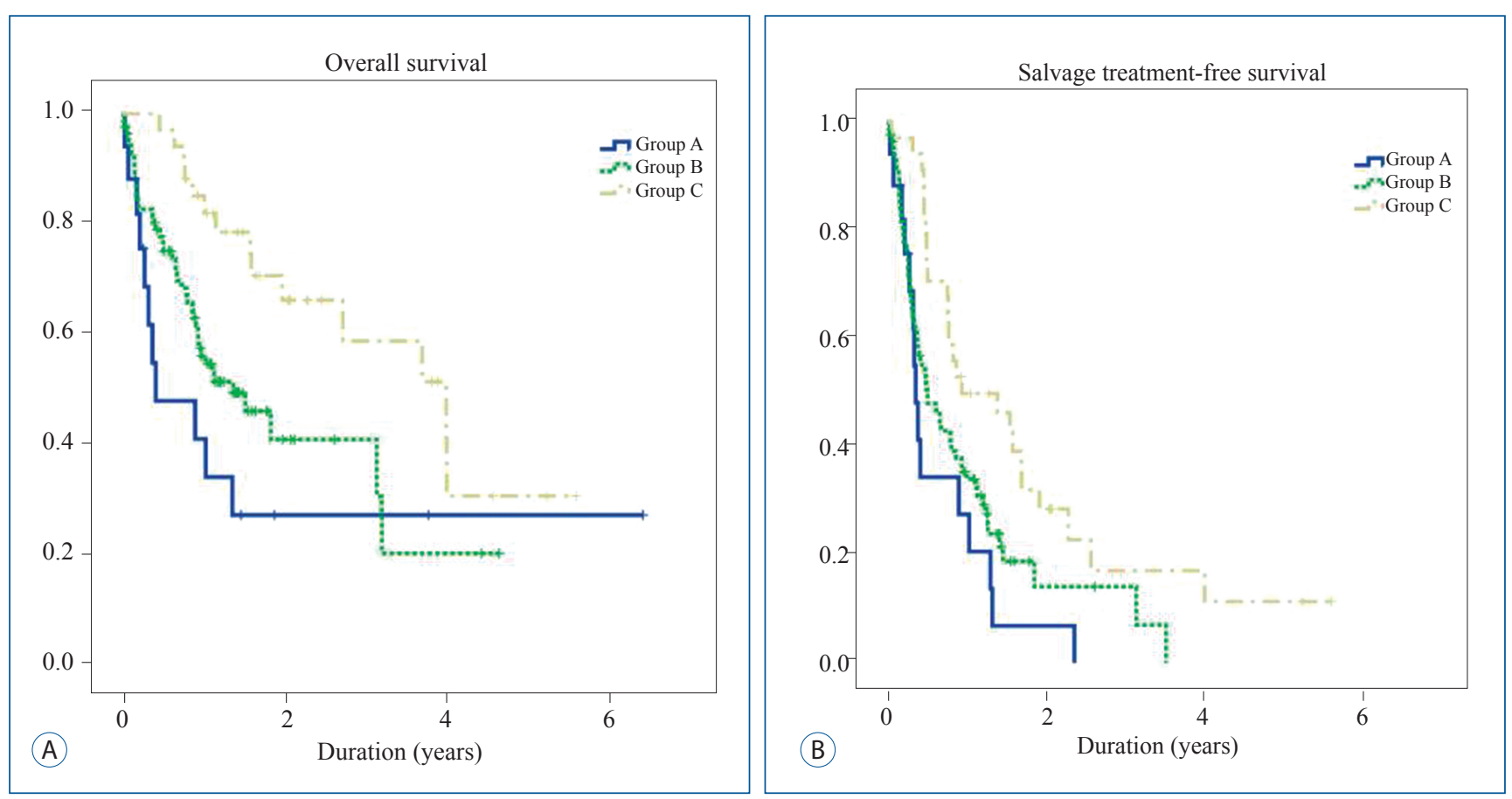

Fig. 1. Kaplan-Meier curve comparing overall survival and salvage treatment-free survival according to the manner of using target agents. Group $A$ : patients who never received target agents; Group B : patients who received target agents before GKS or within 30 days; Group C : patients received target agents 30 days after receiving GKS. GKS: gamma knife radiosurgery.
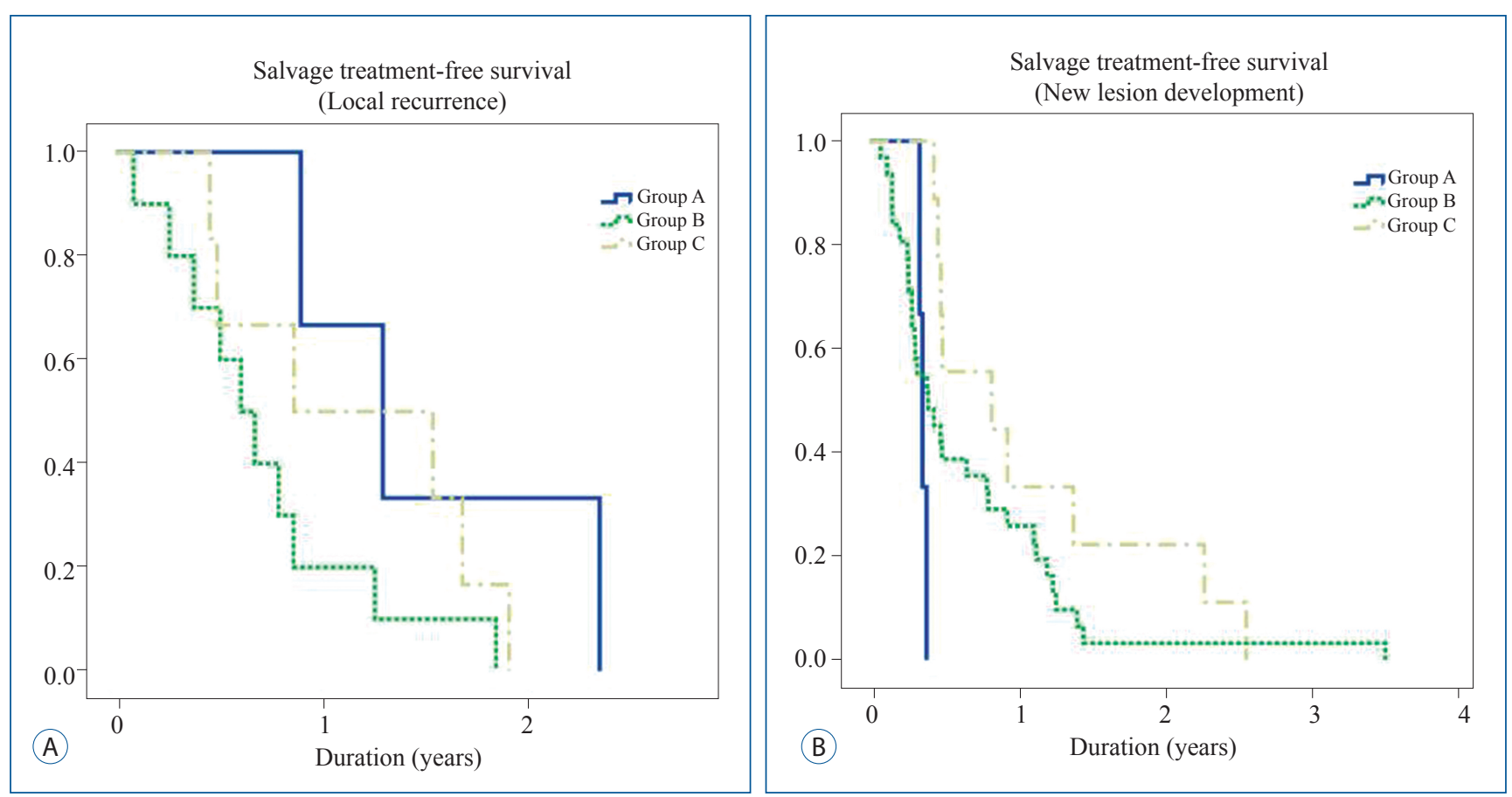

Fig. 2. Kaplan-Meier curve comparing salvage treatment-free survival of the influence of target agents to the pattern of progression, local recurrences and new lesion development. Group A : patients who never received target agents; Group B : patients who received target agents before GKS or within 30 days; Group C : patients received target agents 30 days after receiving GKS. GKS : gamma knife radiosurgery. 
Table 4. Patterns of progression and their treatments

\begin{tabular}{|c|c|c|c|c|c|c|c|c|}
\hline Patterns of progre & ession (n) & $\begin{array}{l}\text { Local recur } \\
\qquad(n=19)\end{array}$ & $\begin{array}{l}\text { New lesion } \\
(n=43)\end{array}$ & $\begin{array}{c}\text { Both (local recur \& } \\
\text { new lesion) } \\
(n=8)\end{array}$ & $\begin{array}{l}\text { LMS } \\
(n=8)\end{array}$ & $\begin{array}{l}\text { Improved } \\
\quad(n=9)\end{array}$ & $\begin{array}{l}\text { Not available } \\
\quad(n=46)\end{array}$ & $\begin{array}{c}\text { Total } \\
(n=134)\end{array}$ \\
\hline $\begin{array}{l}\text { Received salvage } \\
\text { treatment }\end{array}$ & & 14 & 34 & 8 & 7 & & & 63 \\
\hline & GKS & 12 & 31 & 7 & & & & 50 \\
\hline & WBRT & 1 & 2 & 1 & $1^{*}$ & & & 5 \\
\hline & VPS & & $1^{\dagger}$ & & 3 & & & 4 \\
\hline & IT-MTX & & & & 3 & & & 3 \\
\hline & Re-operation & 1 & & & & & & 1 \\
\hline $\begin{array}{l}\text { Not received } \\
\text { salvage treatment }\end{array}$ & & 5 & 9 & & 2 & 9 & 46 & 71 \\
\hline
\end{tabular}

*LMS \& local recurrence. ${ }^{\dagger}$ hydrocephalus \& new lesion. LMS : leptomeningeal seeding, GKS : gamma knife radiosurgery, WBRT : whole brain radiation therapy, VPS : ventricular peritoneal shunt, IT-MTX : intrathecal methotrexate

tions had better prognoses after receiving GKS for brain metastasis in advanced NSCLC. These biomarkers showed powerful prognostic impact in patients with NSCLC and brain metastasis. Previous studies reported that EGFR mutations have no significant effects on progression-free survival or overall survival $^{23,33)}$. In the present study, even though EGFR-TKIs were more frequently prescribed to patients with positive EGFR mutation status, multivariable analysis showed that positive EGFR or ALK mutation status were strong independent prognostic factors. However, since the present study is based on retrospective data, it is impossible to conclude that these biomarkers enhance susceptibility of GKS to brain lesions.

The introduction of target therapies, such as EGFR-TKIs, has broadened the therapeutic options available to NSCLC patients with activating EGFR mutations. EGFR-TKIs are now recommended as a first-line treatment for patients with EGFR mutation-positive NSCLC. Clinical trials demonstrated that first-line treatments with EGFR-TKIs, such as gefitinib or erlotinib, improves progression-free survival compared to chemotherapy ${ }^{25,29,30,35)}$. Meanwhile, pemetrexed and crizotinib have been reported to be effective therapeutic agents for ALK-positive patients $1,{ }^{20)}$. These target agents have recently been used to treat brain metastasis. The role of chemotherapy in the management of brain metastasis remains controversial. Some previous studies showed no benefit or even possibility of deleterious effect. ${ }^{38)}$ However in the cur- rent study, the use of target agents resulted in survival advantage in NSCLC patients with brain metastases. Some series have suggested that subgroups of brain metastases benefit from upfront or post-SRS systemic therapy by improving overall survival, and local control following $\mathrm{SRS}^{13,16,17,24)}$. Because of the specificity of target agents and the various cascades of tumorigenesis across tumor types, the target agents are generally specific to tumor subtype and/or histological subtype. In the present study we found that use of target agents can prolong overall survival and salvage treatmentfree survival in NSCLC patients with brain metastasis. Target agents may enhanced by radiotherapy with synergistic effects, or additive effects from present study. It shows similar result with previous studies ${ }^{6,10,41,42)}$. Analyzing the influence of target agents on the pattern of progression indicated that the manner of target agents had no significant effect. Using target agents did not suppress brain progression, and therefore may affect systemic disease control to prolong the survival of the patient.

The retrospective nature of the study limits our findings to hypothesis generation. There is a possibility of patient selection bias, as patients with improved performance status may be more likely to receive target systemic therapy. In addition, the study was not powered to assess differences between systemic treatments because many patients were prescribed multiple target agents over different periods. Although the genotypes of primary tumors may not reflect those of meta- 
static lesions, most previous studies that have compared EGFR mutation status between primary tumors and corresponding brain metastases have reported a concordance rate of $100 \%{ }^{14,23,27,39)}$. These data suggest that mutational status is conserved in primary tumors and metastatic lesions. Despite its limitations, the results of the current study have broad implications for future prospective trials and the use of target agents in patients with brain metastases in order to help improve the therapeutic ratio of SRS.

\section{CONCLUSION}

In summary, we found that EGFR and ALK mutation status affect the prognoses of patients with brain metastasis and advanced NSCLC. Use of target agents may prolong the survival of patients with advanced NSCLC with brain metastasis after receiving GKS. The present study suggests that the use of target agents combined with GKS leads to superior response rates and markedly prolongs overall survival and salvage treatment-free survival. However, there were no significant effects of target agents in terms of brain lesion control. Target agents may not affect brain lesions directly, but rather prolong survival by controlling systemic disease status.

Target agent therapy might be considered as an alternative management technique for brain metastasis. The effort to identify more accurate biomarkers to predict prognosis and target agents should continue. Well-controlled prospective studies of brain metastasis in advanced NSCLC are needed to further evaluate the effects of target agents on brain lesions.

\section{References}

1. Ahn HK, Jeon K, Yoo H, Han B, Lee SJ, Park H, et al. : Successful treatment with crizotinib in mechanically ventilated patients with ALK positive non-small-cell lung cancer. J Thorac Oncol 8 : 250-253, 2013

2. Alexander E 3rd, Moriarty TM, Davis RB, Wen PY, Fine HA, Black PM, et al. : Stereotactic radiosurgery for the definitive, noninvasive treatment of brain metastases. J Natl Cancer Inst 87 : 34-40, 1995

3. Andrews DW, Scott CB, Sperduto PW, Flanders AE, Gaspar LE, Schell
MC, et al. : Whole brain radiation therapy with or without stereotactic radiosurgery boost for patients with one to three brain metastases: phase III results of the RTOG 9508 randomised trial. Lancet 363 : 1665-1672, 2004

4. Baschnagel AM, Meyer KD, Chen PY, Krauss DJ, Olson RE, Pieper DR, et al. : Tumor volume as a predictor of survival and local control in patients with brain metastases treated with gamma knife surgery. J Neurosurg 119 : 1139-1144, 2013

5. Bhatnagar AK, Flickinger JC, Kondziolka D, Lunsford LD : Stereotactic radiosurgery for four or more intracranial metastases. Int J Radiat Oncol Biol Phys 64 : 898-903, 2006

6. Bianco C, Tortora G, Bianco R, Caputo R, Veneziani BM, Caputo R, et al. : Enhancement of antitumor activity of ionizing radiation by combined treatment with the selective epidermal growth factor receptor-tyrosine kinase inhibitor ZD1839 (Iressa). Clin Cancer Res 8 : 3250-3258, 2002

7. Billing PS, Miller DL, Allen MS, Deschamps C, Trastek VF, Pairolero PC : Surgical treatment of primary lung cancer with synchronous brain metastases. J Thorac Cardiovasc Surg 122: 548-553, 2001

8. Bonnette P, Puyo P, Gabriel C, Giudicelli R, Regnard JF, Riquet M, et al. : Surgical management of non-small cell lung cancer with synchronous brain metastases. Chest 119 : 1469-1475, 2001

9. Chidel MA, Suh JH, Greskovich JF, Kupelian PA, Barnett GH : Treatment outcome for patients with primary nonsmall-cell lung cancer and synchronous brain metastasis. Radiat Oncol Investig 7 : 313-319, 1999

10. Chinnaiyan $P$, Huang $S$, Vallabhaneni $G$, Armstrong $E$, Varambally $S$, Tomlins SA, et al. : Mechanisms of enhanced radiation response following epidermal growth factor receptor signaling inhibition by erlotinib (Tarceva). Cancer Res 65 : 3328-3335, 2005

11. Cho KR, Lee MH, Kong DS, Seol HJ, Nam DH, Sun JM, et al. : Outcome of gamma knife radiosurgery for metastatic brain tumors derived from non-small cell lung cancer. J Neurooncol 125 : 331-338, 2015

12. Choi YL, Sun JM, Cho J, Rampal S, Han J, Parasuraman B, et al. : EGFR mutation testing in patients with advanced non-small cell lung cancer: a comprehensive evaluation of real-world practice in an East Asian tertiary hospital. PLoS One 8 : e56011, 2013

13. Cochran DC, Chan MD, Aklilu M, Lovato JF, Alphonse NK, Bourland JD, et al. : The effect of targeted agents on outcomes in patients with brain metastases from renal cell carcinoma treated with Gamma Knife surgery. J Neurosurg 116 : 978-983, 2012

14. Cortot AB, Italiano A, Burel-Vandenbos F, Martel-Planche $G$, Hainaut $P$ : KRAS mutation status in primary nonsmall cell lung cancer and matched metastases. Cancer $116:$ 2682-2687, 2010

15. Galluzzi S, Payne PM : Brain metastases from primary bronchial carcinoma: a statistical study of 741 necropsies. Br J Cancer 10 : 408-414, 1956

16. Harris $\mathrm{S}$, Chan MD, Lovato JF, Ellis TL, Tatter SB, Bourland JD, et al. : Gamma knife stereotactic radiosurgery as salvage therapy after failure of whole-brain radiotherapy in patients with small-cell lung cancer. Int J Radiat Oncol Biol Phys 83 : e53-59, 2012 
17. Johnson AG, Ruiz J, Hughes R, Page BR, Isom S, Lucas JT, et al. : Impact of systemic targeted agents on the clinical outcomes of patients with brain metastases. Oncotarget 6 : 18945-18955, 2015

18. Karampeazis A, Voutsina A, Souglakos J, Kentepozidis N, Giassas S, Christofillakis $C$, et al. : Pemetrexed versus erlotinib in pretreated patients with advanced non-small cell lung cancer: a Hellenic Oncology Research Group (HORG) randomized phase 3 study. Cancer 119 : 27542764, 2013

19. Knights EM Jr : Metastatic tumors of the brain and their relation to primary and secondary pulmonary cancer. Cancer $7: 259-265,1954$

20. Lee HY, Ahn HK, Jeong JY, Kwon MJ, Han JH, Sun JM, et al. : Favorable clinical outcomes of pemetrexed treatment in anaplastic lymphoma kinase positive non-small-cell lung cancer. Lung Cancer 79 : 40-45, 2013

21. Lee S, Kim Y, Sun JM, Choi YL, Kim JG, Shim YM, et al. : Molecular profiles of EGFR, K-ras, c-met, and FGFR in pulmonary pleomorphic carcinoma, a rare lung malignancy. J Cancer Res Clin Oncol 137 : 12031211, 2011

22. Likhacheva A, Pinnix CC, Parikh NR, Allen PK, McAleer MF, Chiu MS, et al. : Predictors of survival in contemporary practice after initial radiosurgery for brain metastases. Int J Radiat Oncol Biol Phys 85 : 656-661, 2013

23. Luo $D$, Ye $X$, Hu Z, Peng $K$, Song $Y$, Yin $X$, et al. : EGFR mutation status and its impact on survival of Chinese non-small cell lung cancer patients with brain metastases. Tumour Biol 35 : 2437-2444, 2014

24. Luo S, Chen L, Chen X, Xie X: Evaluation on efficacy and safety of tyrosine kinase inhibitors plus radiotherapy in NSCLC patients with brain metastases. Oncotarget 6 : 16725-16734, 2015

25. Maemondo M, Inoue A, Kobayashi K, Sugawara S, Oizumi S, Isobe H, et al. : Gefitinib or chemotherapy for non-small-cell lung cancer with mutated EGFR. N Engl J Med 362 : 2380-2388, 2010

26. Magilligan DJ Jr, Duvernoy C, Malik G, Lewis JW Jr, Knighton R, Ausman $J$ : Surgical approach to lung cancer with solitary cerebral metastasis: twenty-five years' experience. Ann Thorac Surg 42 : 360-364, 1986

27. Matsumoto S, Takahashi K, Iwakawa R, Matsuno Y, Nakanishi Y, Kohno T, et al. : Frequent EGFR mutations in brain metastases of lung adenocarcinoma. Int J Cancer 119 : 1491-1494, 2006

28. Mekhail T, Sombeck M, Sollaccio R : Adjuvant whole-brain radiotherapy versus observation after radiosurgery or surgical resection of one to three cerebral metastases: results of the EORTC 22952-26001 study. Curr Oncol Rep $13: 255-258,2011$

29. Mitsudomi T, Morita S, Yatabe Y, Negoro S, Okamoto I, Tsurutani J, et al. : Gefitinib versus cisplatin plus docetaxel in patients with non-smallcell lung cancer harbouring mutations of the epidermal growth factor receptor (WJTOG3405): an open label, randomised phase 3 trial. Lancet Oncol 11 : 121-128, 2010

30. Mok TS, Wu YL, Thongprasert S, Yang CH, Chu DT, Saijo N, et al. : Gefitinib or carboplatin-paclitaxel in pulmonary adenocarcinoma. N Engl J
Med 361 : 947-957, 2009

31. Newman SJ, Hansen HH: Proceedings: Frequency, diagnosis, and treatment of brain metastases in 247 consecutive patients with bronchogenic carcinoma. Cancer 33 : 492-496, 1974

32. Noordijk EM, Vecht CJ, Haaxma-Reiche H, Padberg GW, Voormolen JH, Hoekstra FH, et al. : The choice of treatment of single brain metastasis should be based on extracranial tumor activity and age. Int J Radiat Oncol Biol Phys 29 : 711-717, 1994

33. Nose N, Sugio K, Oyama T, Nozoe T, Uramoto H, Iwata T, et al. : Association between estrogen receptor-beta expression and epidermal growth factor receptor mutation in the postoperative prognosis of adenocarcinoma of the lung. J Clin Oncol 27 : 411-417, 2009

34. Patchell RA, Tibbs PA, Walsh JW, Dempsey RJ, Maruyama Y, Kryscio RJ, et al. : A randomized trial of surgery in the treatment of single metastases to the brain. N Engl J Med 322 : 494-500, 1990

35. Rosell R, Carcereny E, Gervais R, Vergnenegre A, Massuti B, Felip E, et al. : Erlotinib versus standard chemotherapy as first-line treatment for European patients with advanced EGFR mutation-positive non-small-cell lung cancer (EURTAC): a multicentre, open-label, randomised phase 3 trial. Lancet Oncol $13: 239-246,2012$

36. Schouten LJ, Rutten J, Huveneers HA, Twijnstra A : Incidence of brain metastases in a cohort of patients with carcinoma of the breast, colon, kidney, and lung and melanoma. Cancer 94 : 2698-2705, 2002

37. Sørensen JB, Hansen HH, Hansen M, Dombernowsky P : Brain metastases in adenocarcinoma of the lung: frequency, risk groups, and prognosis. J Clin Oncol 6 : 1474-1480, 1988

38. Sperduto PW, Wang M, Robins HI, Schell MC, Werner-Wasik M, Komaki $\mathrm{R}$, et al. : A phase 3 trial of whole brain radiation therapy and stereotactic radiosurgery alone versus WBRT and SRS with temozolomide or erlotinib for non-small cell lung cancer and 1 to 3 brain metastases: Radiation Therapy Oncology Group 0320. Int J Radiat Oncol Biol Phys 85 : 1312-1318, 2013

39. Sun $M$, Behrens $C$, Feng L, Ozburn N, Tang $X$, Yin $G$, et al. : HER family receptor abnormalities in lung cancer brain metastases and corresponding primary tumors. Clin Cancer Res 15 : 4829-4837, 2009

40. Yamamoto M, Serizawa T, Shuto T, Akabane A, Higuchi Y, Kawagishi J, et al. : Stereotactic radiosurgery for patients with multiple brain metastases (JLGK0901): a multi-institutional prospective observational study. Lancet Oncol 15 : 387-395, 2014

41. Zhuang $H$, Wang J, Zhao L, Yuan Z, Wang P : The theoretical foundation and research progress for WBRT combined with erlotinib for the treatment of multiple brain metastases in patients with lung adenocarcinoma. Int J Cancer 133 : 2277-2283, 2013

42. Zhuang HQ, Sun J, Yuan ZY, Wang J, Zhao LJ, Wang P, et al. : Radiosensitizing effects of gefitinib at different administration times in vitro. Cancer Sci 100 : 1520-1525, 2009 